University of Nebraska - Lincoln

DigitalCommons@University of Nebraska - Lincoln

$6-11-2010$

\title{
Structured Decision-Making and Rapid Prototyping to Plan a Management Response to an Invasive Species
}

\author{
Sean M. Blomquist \\ Tennessee Technological University, seanblomquist@yahoo.com \\ Trisha D. Johnson \\ Tennessee Technological University \\ David R. Smith \\ U.S. Geological Survey, Leetown Science Center \\ Geoff P. Call \\ U.S. Fish and Wildlife Service, Tennessee Ecological Field Office \\ Brant N. Miller \\ Tennessee Wildlife Resources Agency
}

See next page for additional authors

Follow this and additional works at: https://digitalcommons.unl.edu/natrespapers

Part of the Natural Resources and Conservation Commons, Natural Resources Management and Policy Commons, and the Other Environmental Sciences Commons

Blomquist, Sean M.; Johnson, Trisha D.; Smith, David R.; Call, Geoff P.; Miller, Brant N.; Thurman, W. Mark; McFadden, Jamie E.; Parkin, Mary J.; and Boomer, G. Scott, "Structured Decision-Making and Rapid Prototyping to Plan a Management Response to an Invasive Species" (2010). Papers in Natural Resources. 1048.

https://digitalcommons.unl.edu/natrespapers/1048

This Article is brought to you for free and open access by the Natural Resources, School of at DigitalCommons@University of Nebraska - Lincoln. It has been accepted for inclusion in Papers in Natural Resources by an authorized administrator of DigitalCommons@University of Nebraska - Lincoln. 


\section{Authors}

Sean M. Blomquist, Trisha D. Johnson, David R. Smith, Geoff P. Call, Brant N. Miller, W. Mark Thurman, Jamie E. McFadden, Mary J. Parkin, and G. Scott Boomer 


\title{
Articles \\ Structured Decision-Making and Rapid Prototyping to Plan a Management Response to an Invasive Species
}

\author{
Sean M. Blomquist,* Trisha D. Johnson, David R. Smith, Geoff P. Call, Brant N. Miller, W. Mark Thurman, \\ Jamie E. McFadden, Mary J. Parkin, G. Scott Boomer
}

\section{S.M. Blomquist, T.D. Johnson}

Tennessee Technological University, Department of Biology, Box 5063, Cookeville, 38505

D.R. Smith

U.S. Geological Survey, Leetown Science Center, 11649 Leetown Road, Kearneysville, West Virginia 25430

G.P. Call

U.S. Fish and Wildlife Service, Tennessee Ecological Field Office, 446 Neal Street, Cookeville, 38501

\section{B.N. Miller}

Tennessee Wildlife Resources Agency, Real Estate and Forestry Division, P.O. Box 40747, Nashville, 37204

\section{W.M. Thurman}

Tennessee Wildlife Resources Agency, Region III, 464 Industrial Boulevard, Crossville, 38555

\section{J.E. McFadden}

University of Nebraska-Lincoln, School of Natural Resources, 244 Hardin Hall, North Wing, Lincoln, 68583

\section{M.J. Parkin}

U.S. Fish and Wildlife Service, Northeast Regional Office, 300 Westgate Center Drive, Hadley, Massachusetts 01035

\section{G.S. Boomer}

U.S. Fish and Wildlife Service, Division of Migratory Bird Management, 11510 American Holly Drive, Laurel, Maryland 20708

\begin{abstract}
We developed components of a decision structure that could be used in an adaptive management framework for responding to invasion of hemlock woolly adelgid Adeleges tsugae on the Cumberland Plateau of northern Tennessee. Hemlock woolly adelgid, an invasive forest pest, was first detected in this area in 2007. We used a structured decision-making process to identify and refine the management problem, objectives, and alternative management actions, and to assess consequences and tradeoffs among selected management alternatives. We identified four fundamental objectives: 1) conserve the aquatic and terrestrial riparian conservation targets, 2) protect and preserve hemlock, 3) develop and maintain adequate budget, and 4) address public concerns. We designed two prototype responses using an iterative process. By rapidly prototyping a first solution, insights were gained and shortcomings were identified, and some of these shortcomings were incorporated and corrected in the second prototype. We found that objectives were best met when management focused on early treatment of lightly to moderately infested but relatively healthy hemlock stands with biological control agent predator beetles and insect-killing fungi. Also, depending on the cost constraint, early treatment should be coupled with silvicultural management of moderately to severely infested and declining hemlock stands to accelerate conversion to nonhemlock mature forest cover. The two most valuable contributions of the structured decision-making process were 1) clarification and expansion of our objectives, and 2) application of tools to assess tradeoffs and predict consequences of alternative actions. Predicting consequences allowed us to evaluate the influence of uncertainty on the decision. For example, we found that the expected number of mature forest stands over $30 \mathrm{y}$ would be increased by $4 \%$ by resolving the uncertainty regarding predator beetle effectiveness. The adaptive management framework requires further development including identifying and evaluating uncertainty, formalizing other competing predictive models, designing a monitoring program to update the predictive models, developing a process for re-evaluating the predictive models and incorporating new management technologies, and generating support for planning and implementation.
\end{abstract}

Keywords: rapid prototype; adaptive management; structured decision-making; decision analysis; hemlock woolly adelgid; invasive species; Cumberland Plateau

Received: December 7, 2009; Accepted: March 23, 2010; Published: June 11, 2010 (delayed for inaugural issue)

Citation: Blomquist SM, Johnson TD, Smith DR, Call GP, Miller BN, Thurman WM, McFadden JE, Parkin MJ, Boomer GS. 2010. Structured decision-making and rapid prototyping to plan a management response to an invasive species. Journal of Fish and Wildlife Management 1(1):19-32; e1944-687X. doi: 10.3996/JFWM-025

Copyright: All material appearing in the Journal of Fish and Wildlife Management is in the public domain and may be reproduced or copied without permission. Citation of the source, as given above, is requested. 
The findings and conclusions in this article are those of the author(s) and do not necessarily represent the views of the U.S. Fish and Wildlife Service.

* Corresponding author: seanblomquist@yahoo.com

\section{Introduction}

Successfully reducing populations of invasive species requires complex decisions and coordinated action across multiple spatial scales, temporal scales, and scales of governance (Pimentel et al. 2005; Graham et al. 2008). Often the frequency of decisions may occur over daily to decadal temporal scales and across local to continental spatial scales. These decisions may result from policies originating at a local to international level. For example, response to spread of invasive quagga Dreissena rostriformis bugensis and zebra mussels $D$. polymorpha beyond the North American Great Lakes required massive planning and coordination among state and provincial agencies, United States and Canadian federal agencies, and many other organizations over two decades (Drake and Bossenbroek 2004). Inaction or delayed responses to invasive species can result in high economic costs and loss of biodiversity (e.g., Leung et al. 2002; Rohr et al. 2009).

Adaptive management is a special case of structured decisionmaking that can provide transparency to decision-making under uncertainty and an approach to learning from management actions (Keeney and Raiffa 1993; Nichols and Williams 2006; Gregory and Long 2009). A structured decision-making approach uses specific steps for framing the management problem, identifying objectives, choosing feasible management alternatives, modeling system dynamics, monitoring system response to management, and updating relative beliefs in predictive models (e.g., Johnson et al. 1997; Hammond et al. 1999). A structured decision-making process can be extremely effective at targeting responses to conservation and management problems (Gregory and Keeney 2002). Portions of these decision tools are routine in pest management. For example, integrated pest management as implemented by the United States Environmental Protection Agency uses management thresholds for insect pest populations to trigger use of possible management options and monitor the outcome of management. However, structured decision-making and adaptive management have rarely been used to design and implement management strategies for invasive species (e.g., Bogich and Shea 2008).

Hemlock woolly adelgid Adeleges tsugae is native to Asia and was introduced to the eastern United States from Japan in the early 1950s (Havill et al. 2006). It has since spread throughout the eastern United States in eastern hemlock Tsuga canadensis and Carolina hemlock $T$. caroliniana forests at a rate of $>15 \mathrm{~km} / \mathrm{y}$ and, consequently, has become a forest pest of management concern (McClure et al. 2001; Evans and Gregoire 2007). Hemlock woolly adelgid can cause $>60 \%$ mortality of hemlocks in infested stands in $<12 \mathrm{y}$, which results in a series of subsequent ecosystem-level effects, including a decrease in soil moisture and the uptake of water and nitrogen and an increase in decomposition and the nitrogen content of rainwater throughfall (e.g., Orwig et al. 2002, 2008). Hemlock woolly adelgid invaded eastern Tennessee in 2002 (Kirksey et al. 2004; Soehn et al. 2005) and has been detected in several counties on the Cumberland Plateau (USFS 2009).

The forest management and conservation community (e.g., Tennessee state land management agencies, The Nature
Conservancy) is concerned about the potential spread of the pest in the state because hemlocks are a major component of riparian ecosystems on the Cumberland Plateau in Tennessee. Tennessee Wildlife Resources Agency (TWRA) owns and manages approximately 89,000 ha $(220,000$ acres $)$ on the Cumberland Plateau. Hemlock-containing communities comprise approximately 20,600 ha $(51,000$ acres $)$ or $23 \%$ of TWRA-owned lands in the region. As part of forest management practices, TWRA uses riparian buffers to protect streams from possible effects of timber harvesting and provide forested corridors for wildlife in areas harvested for timber. Because the overstory canopy of many riparian areas on the Cumberland Plateau is dominated by hemlock trees, invasion of hemlock woolly adelgid could compromise the effectiveness of these riparian buffers as forested corridors for federally listed forest-dependent species (e.g., Indiana bat Myotis sodalis) and for protecting aquatic habitat for federally listed aquatic species (e.g., blackside dace Phoxinus cumberlandensis), as well as affect other ripariandependent conservation targets (e.g., Swainson's warbler Limnothlypis swainsonii, and Alleghany woodrat Neotoma magister).

In 2004 the state land management agencies (TWRA; Department of Environment and Conservation Divisions of Parks, Natural Heritage, and State Natural Areas; Department of Agriculture Division of Forestry) and U.S. Forest Service formed the Tennessee Interagency Hemlock Woolly Adelgid Task Force and developed a strategic response plan for detecting and managing the spread of this pest (Kirksey et al. 2004). As part of this task force, TWRA has invested in development of biological control agents including two predator beetles, Sasajiscymnus tsugae and Laricobius nigrinus, and an insect-killing fungus, Lecanicillium muscarium.

To further advance our understanding of optimal management responses to the invasion of hemlock wooly adelgid on the northern Cumberland Plateau in Tennessee, we formed a team of biologists and foresters from TWRA, U.S. Fish and Wildlife Service (USFWS), and the Northern Cumberlands Forest Resources Habitat Conservation Plan (NCFRHCP) to apply structured decision-making to this issue. Tennessee Wildlife Resources Agency is currently developing the NCFRHCP to allow continuation of forest management activities on four wildlife management areas on the Cumberland Plateau, and this plan has identified approximately 45 conservation targets (hereafter, covered species). Decision makers on the team included a nongame biologist (W.M.T.) and forester (B.N.M.) from TWRA and an endangered species biologist from USFWS (G.P.C.); the USFWS must approve the amount of take allowed under the incidental take permit issued to TWRA under the Endangered Species Act and, hence, also influences the decision. Two conservation coordinators (S.M.B., T.D.J.) from the NCFRHCP comprised the remainder of the team. This team attended a USFWS and U.S. Geological Survey (USGS)-sponsored workshop that provided technical assistance on structured decision-making and rapid prototyping. With assistance of structured decision-making experts from the USFWS (M.J.P., G.S.B.), USGS (D.R.S.), and University of Nebraska (J.E.M.), we planned a response for management of hemlock stands when hemlock woolly adelgid is detected on TWRA-managed lands. 
In this paper, we report on the process used to identify a management response to hemlock woolly adelgid invasion. We sequentially present the prototyped decision frameworks to demonstrate how insights from the first prototype were incorporated into the design of the second prototype. We conclude with a discussion on the value and limitations of the rapid-prototyping process and propose further development of an adaptive management framework.

\section{The PrOACT Process}

During the workshop, the team iterated through a structured decision-making process (Hammond et al. 1999; Gregory and Long 2009) and developed two prototype management responses to invasion of hemlock woolly adelgid. The steps of the process can be summarized as identifying the problem, clarifying the objectives, generating alternative actions, predicting consequences of the actions in terms of the objectives, and evaluating tradeoffs. Hammond et al. (1999) used PrOACT as shorthand for the steps in the process. Problem identification is a critical driver for subsequent steps of the process and, for each iteration, the team reframed the problem to improve specific aspects. This led to distinct two problem statements and management solutions. The primary difference between the problem statements was that the second iteration focused on a single objective (i.e., maintenance of mature riparian forest cover). The second problem statement also defined the spatial scale and temporal framework for the decision (Table 1). This refinement allowed us to make progress building a mathematical model to predict likely consequences of alternative management responses and evaluate which responses best addressed our overriding objectives.

After defining our problem, we articulated a set of fundamental objectives and built an objectives hierarchy. We defined a range of management options and the ecological conditions under which each alternative might be considered for a given forest stand. During the first prototype, we developed a conceptual model (i.e., an influence diagram) and assessed consequences of the management alternatives and tradeoffs among the multiple objectives in the first iteration. The insights that we gained by assessing tradeoffs in the first prototype were used to ultimately choose a single fundamental objective to focus our decision analysis during the second iteration. One advantage of the structured decision-making process is that it explicitly incorporates uncertainty and uses sensitivity analysis to ensure the most robust decision possible in the face of this uncertainty. Focus on a single objective and refining treatment alternatives helped to develop mathematical models incorporating assumptions and uncertainties to describe how the treatment alternatives interacted with ecological processes to influence hemlock woolly adelgid invasion at the stand ( $~ 8$ ha [20 acres]) and wildlife management area $(\sim 89,000$ ha $[220,000$ acres]) scales, and we used the model to assess the consequences of implementing the management alternatives and to evaluate the influence of uncertainty.

The two iterations of the PrOACT process enabled us to gain insights and refine the prototype solutions. As we worked through the process, we identified and discussed key elements including the spatial scale for hemlock woolly adelgid treatment, the type of treatments to apply, the ecological condition of hemlock stands and its relationship to treatment, and the proximity of the stands to known occurrences and habitat of species covered by the NCFRHCP. In the first iteration, we gained the crucial insight that maintaining mature riparian forest was the objective that was fundamentally important to the team and would subsume other ecological objectives. The second prototype focused on developing a decision framework for this fundamental objective, and took into consideration the need to adaptively manage for hemlock woolly adelgid invasion on lands within the NCFRHCP project area. Ultimately, a fully adaptive management program will require further development of predictive models and optimization methods, as well as coordination of monitoring programs to be used for assessing the state of the system and updating relative beliefs in our models through an adaptive process. Nonetheless, the initial framework provides the foundation for reducing significant uncertainties while informing future decisions through an adaptive management response to invasion of hemlock woolly adelgid in Tennessee.

\section{Prototype Solutions}

\section{The first prototype}

Problem. We identified a vague problem statement prior to the workshop, which required significant revision for the first prototype. For the first prototype we identified the decision makers, location, multiple objectives, and uncertainties as key parts of our problem (Table 1).

Objectives. Our first rapid prototype included multiple fundamental objectives: 1) conserve the NCFRHCP-covered aquatic and terrestrial riparian species, 2) protect and preserve hemlock, 3) develop and maintain adequate budget, and 4) address public concerns. For each fundamental objective, we developed measurable attributes and performance criteria to gauge success in meeting each of the fundamental objectives (Figure 1). For example, the measurable attribute for the budget objective was cost of mitigation and treatment, and the performance criterion was to minimize dollars spent.

Alternative management actions. The management actions we initially considered focused solely on treatment of hemlock woolly adelgid. We expanded the management actions to help mitigate possible ecosystem effects due to loss of mature forest canopy surrounding streams. These management options were intended to provide habitat for riparian-dependent covered species (e.g., Swainson's warbler and Alleghany woodrat), maintain stream temperatures, reduce fluctuations in water flows, and decrease sediment input due to loss of mature forest cover for aquatic covered species (e.g., blackside dace). Possible actions were categorized according to their treatment of hemlock woolly adelgid, forest cover (i.e., silvicultural treatment), or riparian buffer widths (Table 2). Silvicultural treatments reduced the amount of time a stream lacked mature forest cover. Alternative riparian buffers widths within harvested stands were modified from status quo (e.g., $91.4 \mathrm{~m}$ [300 ft] on each side of the stream).

The team struggled with decisions concerning the scale of management. The primary source of confusion was whether to consider treatments at the scale of the entire management area or at the individual stand scale. We had a lengthy discussion about the scale at which the alternative actions would operate and found that the perceived scale varied among team members. Thus, we agreed for the purposes of the first prototype, to consider actions applied to individual stands. We further reduced complexity of the decision framework by focusing on how to manage the hemlock stands possessing the most desirable ecological characteristics; hereafter, a highquality hemlock stand (Table 3 ). We defined a high-quality hemlock stand as having $>50 \%$ hemlock overstory canopy 
Table 1. Problem statements for the two rapid prototypes of the structured decision-making process for invasion of hemlock woolly adelgid on the Cumberland Plateau of Tennessee.

\begin{tabular}{ll}
\hline Prototype & \multicolumn{1}{c}{ Problem statement } \\
\hline First & $\begin{array}{l}\text { Tennessee Wildlife Resources Agency in consultation with the United States Fish and Wildlife Service through a habitat conservation plan and } \\
\text { incidental take permitting process will manage state wildlife management areas to maintain mature forest cover and native species } \\
\text { composition within riparian buffers. Hemlock woolly adelgid is an acute and present threat to the structure and composition of riparian areas in } \\
\text { the Cumberland Plateau and Mountains, where hemlock is a significant component. Because effectiveness of hemlock woolly adelgid control is } \\
\text { uncertain, information gained will be incorporated into future decisions. }\end{array}$ \\
\hline Second & $\begin{array}{l}\text { Tennessee Wildlife Resources Agency, in consultation with the United States Fish and Wildlife Service through the habitat conservation plan } \\
\text { and incidental take permitting process, will decide annually how to manage hemlock woolly adelgid infestation 1) to maintain hemlock- and } \\
\text { hardwood/pine-dominated mature forest cover within riparian buffers of wildlife management areas totaling 220,000 acres and 2) to avoid or } \\
\text { minimize the take of federally listed species over the next } 30 \text { y. Because effectiveness of hemlock woolly adelgid control is uncertain, } \\
\text { information gained will be incorporated into future decisions through an adaptive management framework. }\end{array}$ \\
\hline
\end{tabular}

cover, $>4.0$ ha (10 acres) in spatial extent, less advanced understory tree regeneration or a Rhododendron spp.-dominated understory, and presence of NCFRHCP covered species. Additionally, the hemlocks in the stand were in healthy condition ( $<10 \%$ mortality, $11-25 \%$ defoliation; Kirksey et al. 2004). We included stands with less advanced understory tree regeneration or a Rhododendron spp.-dominated understory as a desired ecological characteristic primarily because it eliminated silvicultural options from consideration for the first prototype. Criteria to describe hemlock stand health and degree of hemlock woolly adelgid infestation were based on the Hemlock Woolly Adelgid Strategic Plan and Management Plan for State Lands in Tennessee (Kirksey et al. 2004).

Portfolios of alternative actions were developed by choosing from our list of possible management options for hemlock woolly adelgid (Table 2). We created the following three portfolios that could be applied to high-quality hemlock stands: 1) the status quo (i.e., existing TWRA program for applying hemlock woolly adelgid treatments), 2) maximizing hemlock protection, and 3) minimizing take of NCFHCP covered species over a 30-y time horizon (Table 4).
Examining consequences. We created a conceptual model (i.e., an influence diagram), to identify potential linkages between management actions and the measurable attributes that defined our fundamental objectives (Figure 2). For our initial conceptual model, we relied on available information and expert opinion. These linkages then formed the basis of a decision analysis where we evaluated predicted outcomes in response to the management actions, using a consequence table (Table 5). This allowed us to examine the consequences and compare the relative performance of the three portfolio alternatives. The key finding of this analysis was that the portfolio that aimed to maximize hemlock protection performed best for all ecological objectives despite its poor performance for cost and public concern. This exposed inherent tradeoffs among the objectives and indicated that analysis of the tradeoffs would depend on the preference or value placed on the objectives.

Tradeoff analysis. The consequence table provided the basis for analyzing the tradeoffs among our fundamental objectives (Table 5). We used swing weighting to quantify each team member's relative preferences among the fundamental objectives given the expected change in the performance

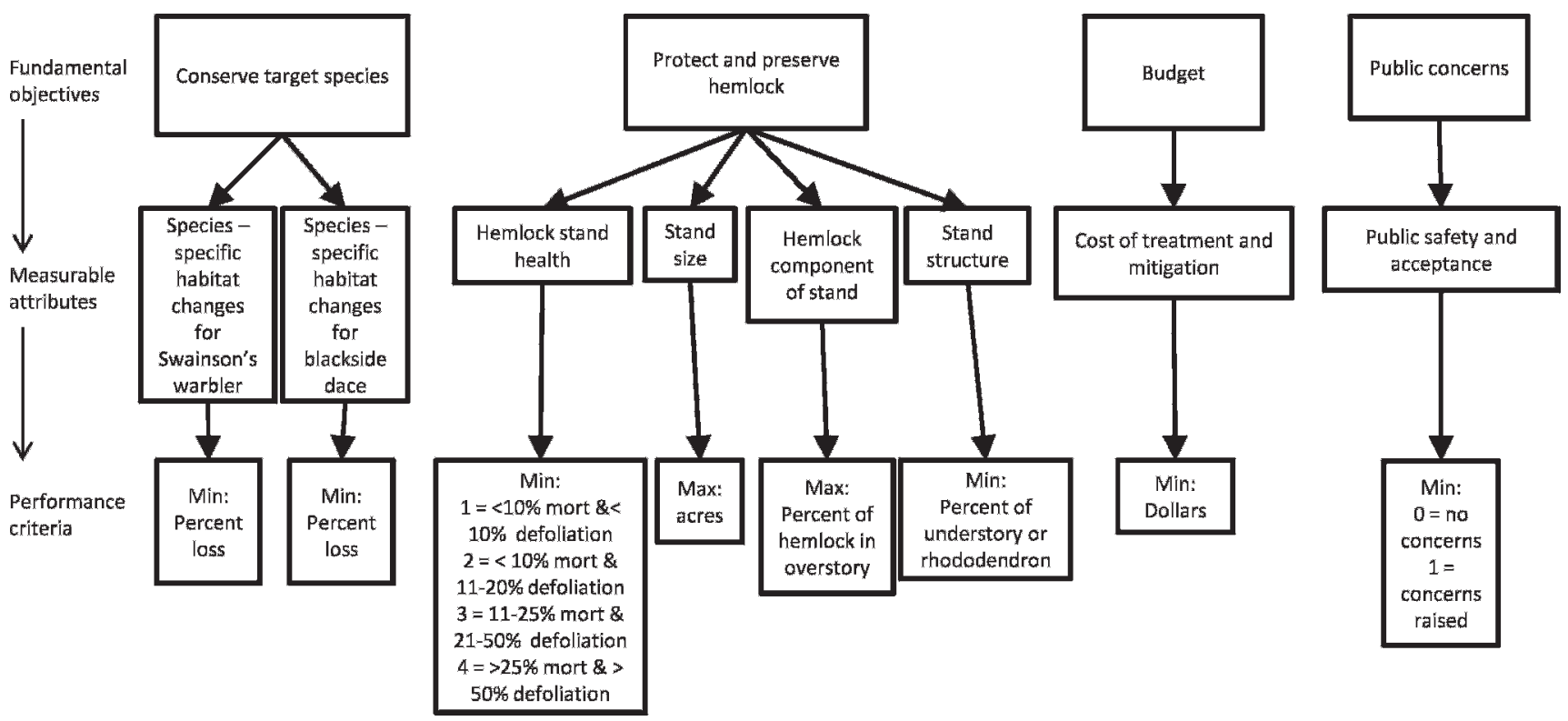

Figure 1. Fundamental objectives, measureable attributes, and performance criteria for protection of hemlocks and conservation of two conservation targets, blackside dace Phoxinus cumberlandensis and Swainson's warbler Limnothlypis swainsonii. We added a third conservation target, Alleghany woodrat Neotoma magister, during the second prototype. For hemlock stand characteristics that we will protect with treatments, we want to maximize the size of stands, maximize the dominance of hemlock, and minimize the understory competition for hemlock regeneration. Mort indicates mortality. 
Table 2. Strategy table showing alternative management actions available for hemlock woolly adelgid invasion on the Cumberland Plateau of Tennessee; treatments are listed from least to most intensive based on cost and potential impact on the environment.

\begin{tabular}{lll}
\hline \multicolumn{1}{c}{ Silviculture } & Treatment category \\
\hline Hemlock woolly adelgid & \multicolumn{1}{c}{ Riparian buffer } \\
\hline No treatment & No silviculture & Decrease buffer size \\
\hline Fungal spray & Site preparation-prescribed burn & Retain 61-m (200-ft) no-harvest zone \\
\hline Predator beetles & Understory release-chemical & Expand buffer size by 61.0 m (200 ft) where hemlock stands are lost \\
\hline Horticultural oils or soaps & Understory release-mechanical & \\
Soil injection of imidacloprid & Site preparation-chemical with planting & \\
\hline Tree injection of imidacloprid & Site preparation-mechanical with planting & \\
& Tree removal & \\
\hline
\end{tabular}

criteria (Keeney and Raiffa 1993). We normalized scores and averaged team member preferences to assign weights to the fundamental objectives for our final tradeoff analysis. Most weight (81\%) was placed on the ecological objectives, with $44 \%$ on the fundamental objective to conserve target species. Cost and public concern received $19 \%$ of the weighting. Based on the final scores, the portfolio that focused on maximizing hemlock protection was $>1.4$ times more effective at meeting the weighted objectives than the status quo management or the portfolio that focused on minimizing take of covered species (Table 5).

\section{The second prototype}

Problem and objectives. Because the portfolio that aimed to maximize hemlock protection was the most effective at meeting our fundamental objectives in the first prototype, we chose to focus on the ecological objectives (i.e., preserve hemlock and NCFRHCP-covered species) and treat the remaining fundamental objectives as constraints in the second prototype (Figure 1). The team agreed that none of the proposed management actions would pose an unacceptable public concern, so cost was the remaining constraint. We also expanded the scope of the problem by framing it as a sequential decision process, recognizing that management options may change over a 30-y planning horizon. However, we did not explicitly incorporate this horizon in the simulations performed during the workshop. As reflected in the revised problem statement (Table 1), we also considered preservation or creation of mature hardwood- and pine-dominated riparian forests because this mature riparian forest type is an additional important habitat for the covered species. To help measure success at preserving this habitat, we added one target species to our objectives hierarchy (Alleghany woodrat), because this species prefers mature hardwood

Table 3. Hemlock stand health condition and infestation categories. Descriptions for each category of stand health and infestation are based on categories monitored by Tennessee state foresters (Kirksey et al. 2004). We defined a healthy hemlock stand for the first rapid prototype as one with light or no hemlock woolly adelgid infestation (none and light categories) and in the healthy hemlock stand decline category. We assessed all categories in the second rapid prototype.

\begin{tabular}{|c|c|c|}
\hline Index & Category & Description \\
\hline \multirow[t]{4}{*}{ Hemlock woolly adelgid infestation } & None & No adelgids observed. \\
\hline & Light & Most trees are uninfested or most infested trees have $<10 \%$ of infested branches. \\
\hline & Moderate & $\begin{array}{l}26-50 \% \text { of the trees appear to be infested and most often individual trees have }<50 \% \text { of } \\
\text { the branches infested. }\end{array}$ \\
\hline & Heavy & $\begin{array}{l}>50 \% \text { of the trees are infested and most often the majority of the branches on individual } \\
\text { trees are infested. }\end{array}$ \\
\hline \multirow[t]{4}{*}{ Hemlock stand decline } & Healthy & $\begin{array}{l}\text { Trees appear to be in reasonably good health with }<10 \% \text { of the trees showing signs of } \\
\text { stress such as defoliation, needle discoloration or branch tip dieback. Hemlock mortality } \\
<10 \% \text { throughout the stand. }\end{array}$ \\
\hline & Light decline & $\begin{array}{l}\text { Trees appear minimally stressed with many trees showing } 11-25 \% \text { defoliation, needle } \\
\text { discoloration or branch tip dieback. Larger branch mortality may be present but not } \\
\text { frequent on trees within the stand. Hemlock mortality }<10 \% \text { throughout the stand. }\end{array}$ \\
\hline & Moderate decline & $\begin{array}{l}\text { Trees generally appear under stress with most trees showing } 26-50 \% \text { defoliation, needle } \\
\text { discoloration or tip dieback. Larger branch mortality is relatively common throughout the } \\
\text { stand. Hemlock mortality } 11-25 \% \text { throughout the stand. }\end{array}$ \\
\hline & Severe decline & $\begin{array}{l}\text { Trees appear obviously stressed with most trees showing }>50 \% \text { defoliation, needle } \\
\text { discoloration or branch tip dieback. Larger branch mortality is common throughout the } \\
\text { stand. Hemlock mortality may be }>25 \% \text { throughout the stand. }\end{array}$ \\
\hline
\end{tabular}


Table 4. Alternative management portfolios considered during the first prototype. See Table 2 for more details on management options.

\begin{tabular}{llll}
\hline & \multicolumn{1}{c}{ Management portfolio } & \\
\cline { 2 - 4 } Treatment category & \multicolumn{1}{c}{ Status quo } & Maximize hemlock protection & \multicolumn{1}{c}{$\begin{array}{l}\text { Minimize take of habitat } \\
\text { conservation plan species }\end{array}$} \\
\hline Hemlock woolly adelgid & Both predator beetle species & $\begin{array}{l}\text { Both predator beetle species, fungi, and both } \\
\text { imidacloprid options (soil and tree injection) }\end{array}$ & Both predator beetle species and fungi \\
Silviculture & No silviculture & No silviculture & No silviculture \\
\hline Riparian buffer & Retain 61-m (200-ft) no-harvest zone & Retain 61-m (200-ft) no-harvest zone & $\begin{array}{l}\text { Expand buffer size by } 61.0 \mathrm{~m}(200 \mathrm{ft}) \text { on } \\
\text { both sides of stand }\end{array}$ \\
\hline
\end{tabular}

forests and may respond differently to the creation of mature hardwood- and pine-dominated forests.

Alternative management actions and developing a predictive model. We defined five states of riparian forest stands that represent a progression from healthy hemlock stands through infestation with hemlock woolly adelgid to mature hardwood- or pine-dominated stands, and we considered five actions based on the first prototype. The five states were based on a matrix of the monitoring criteria for hemlock stand decline and hemlock woolly adelgid infestation categories in the Hemlock Woolly Adelgid Strategic Plan and Management Plan for State Lands in Tennessee (Table 3; Kirksey et al. 2004). We eliminated potential states that were unlikely to exist in nature or unlikely to be managed, and we included a mature hardwood- or pine-dominated stand as transition after hemlock loss as a fifth state. The following five states of riparian forest stands helped to build a state-based predictive model of the hemlock woolly adelgid invasion system: $\mathrm{HH}=$ healthy hemlock stand, LH = lightly infested and healthy to lightly declining hemlock stand, $\mathrm{MH}=$ moderately to severely infested and moderately declining hemlock stand, $\mathrm{SH}=$ moderately to severely infested and severely declining hemlock stand, and MHP = mature hardwood- or pinedominated stands (Figure 3). We assessed alternative

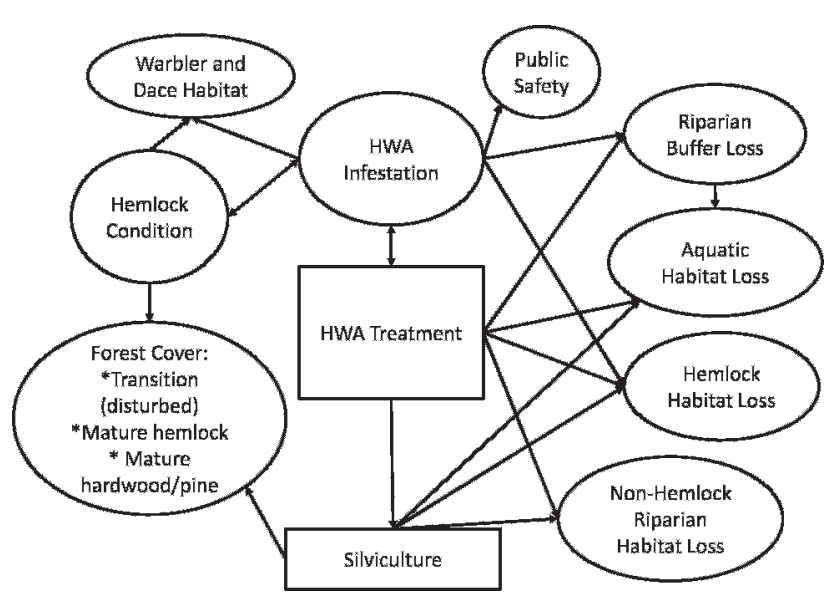

Figure 2. Conceptual influence diagram for the first prototype illustrating how treatment for hemlock woolly adelgid (HWA) could affect the performance criteria of our four fundamental objectives (Figure 1). We considered four hemlock health conditions in the decision process (none, low, moderate, and high) that may exhibit different rates of infestation based on the initial hemlock health condition at time of first exposure to HWA. Combined, the initial condition and level of infestation determined which management action was implemented. treatments that might be applied to these five states by considering which treatments from the first prototype would be applied depending on state of the riparian forest stand (Table 4).

We thus created a state-based predictive model (Figure 3) that illustrated possible transitions among the five riparian forest stand condition and infestation states. The model provided the basis for predicting consequences and tradeoffs among management actions. Transitions between states in the model can occur due to colonization (c), growth (g), and extinction/decline $(d$, the probability of a moderately infested stand declining to a light infestation; $e_{h}$, the probability of a lightly infested stand going extinct; or $e_{p}$, the probability of a severely infested stand going extinct). State-based transitions from time $t-1$ to time $t$ can be described using the following equations:

$$
\begin{aligned}
H H_{t} & =H H_{t-1}(1-c)+L H_{t-1} e_{h}, \\
L H_{t} & =L H_{t-1}\left(1-e_{h}-g\right)+H H_{t-1} C+M H_{t-1} d, \\
M H_{t} & =M H_{t-1}(1-d-g)+L H_{t-1} g, \\
S H_{t} & =S H_{t-1}\left(1-e_{p}\right)+M H_{t-1} g, \\
M H P_{t} & =M H P_{t-1}+S H_{t-1} e_{p} .
\end{aligned}
$$

These relationships assume that states can only move one state during each time step in the model. Although we initially investigated a linearly increasing colonization rate $(c)$ of uninfested hemlock stands, we felt this was unrealistic for an invasion. We instead used an exponentially increasing colonization rate to describe the way hemlock woolly adelgid spread across the landscape, where

$$
c=\beta_{0} e^{\left(\beta_{1} \frac{\Sigma s_{i}}{s_{j}}\right)}
$$

and $\beta_{0}$ is the intercept, which we defined as $0.01 ; \beta_{1}$ is the slope, which we defined as $4.61 ; s_{i}$ is the number of stands in one of the three infested states $i$; and $s_{j}$ is the total number of stands. This nonlinear colonization rate model assumes an exponentially increasing likelihood of a new stand being colonized as the landscape becomes saturated with infested stands. Exponentially increasing population growth rate has been suggested for many terrestrial invasive species (Grosholz 1996); further, known rates of hemlock woolly adelgid spread on the landscape in the southern portion of the range in the 
Table 5. Raw scores and normalized, weighted scores that were used to assess consequences and tradeoffs among the three alternative management portfolios in the first prototype. Raw scores were normalized to a scale of $0-1$, and weights based on team member preferences for each alternative were applied to each normalized score. We assessed how well each portfolio met the performance criteria for the four fundamental objectives (Figure 1). We standardized stand size and structure for this analysis ( $>4$ ha [10 acres], less advanced understory tree regeneration or a Rhododendron spp.-dominated understory); these stand attributes are not included.

\begin{tabular}{|c|c|c|c|c|c|c|c|c|c|}
\hline \multirow[b]{2}{*}{ Objectives } & \multirow[b]{2}{*}{ Goal } & \multirow[b]{2}{*}{ Units } & \multicolumn{3}{|c|}{ Raw scores for portfolios } & \multirow[b]{2}{*}{ Weight } & \multicolumn{3}{|c|}{$\begin{array}{l}\text { Normalized, weighted } \\
\text { scores for portfolios }\end{array}$} \\
\hline & & & $\begin{array}{l}\text { Status } \\
\text { quo }\end{array}$ & $\begin{array}{l}\text { Maximize } \\
\text { hemlock } \\
\text { protection }\end{array}$ & $\begin{array}{l}\text { Minimize take } \\
\text { of habitat } \\
\text { conservation } \\
\text { plan species }\end{array}$ & & $\begin{array}{l}\text { Status } \\
\text { quo }\end{array}$ & $\begin{array}{l}\text { Maximize } \\
\text { hemlock } \\
\text { protection }\end{array}$ & $\begin{array}{c}\text { Minimize take } \\
\text { of habitat } \\
\text { conservation } \\
\text { plan species }\end{array}$ \\
\hline $\begin{array}{l}\text { Swainson's warbler } \\
\text { habitat loss }\end{array}$ & Minimize & \% Decline & 32.50 & 10.00 & 17.50 & 0.23 & 0.00 & 0.23 & 0.16 \\
\hline $\begin{array}{l}\text { Blackside dace } \\
\text { habitat loss }\end{array}$ & Minimize & \% Decline & 5.00 & 2.50 & 4.00 & 0.21 & 0.00 & 0.21 & 0.08 \\
\hline $\begin{array}{l}\text { Hemlock stand } \\
\text { health }\end{array}$ & Minimize & $\begin{array}{l}1-4 \text { scale } \\
(1=\text { healthy })\end{array}$ & 4.00 & 2.00 & 3.00 & 0.22 & 0.00 & 0.22 & 0.11 \\
\hline $\begin{array}{l}\text { Hemlock } \\
\text { component }\end{array}$ & Maximize & $\begin{array}{l}\% \text { of hemlock } \\
\text { in overstory }\end{array}$ & 32.50 & 45.00 & 40.00 & 0.16 & 0.00 & 0.16 & 0.10 \\
\hline $\begin{array}{l}\text { Cost of treatment } \\
\text { and mitigation }\end{array}$ & Minimize & Dollars & 7.00 & 30.00 & 18.00 & 0.14 & 0.14 & 0.00 & 0.07 \\
\hline Public concerns & Minimize & $\begin{array}{l}0=\text { no concern; } \\
1=\text { concern }\end{array}$ & 0.00 & 1.00 & 0.00 & 0.05 & 0.05 & 0.00 & 0.50 \\
\hline Final score & & & & & & & 0.19 & 0.82 & 0.57 \\
\hline
\end{tabular}

eastern United States are higher than in the northern United States (Evans and Gregoire 2007).

We used available data and opinion to parameterize our initial model. We then developed predictive relationships between the set of management actions and expected changes in the transition probabilities (Table 6). Hemlock woolly adelgid populations are known to induce heavy mortality and defoliation in hemlock stands (e.g., severe decline category;

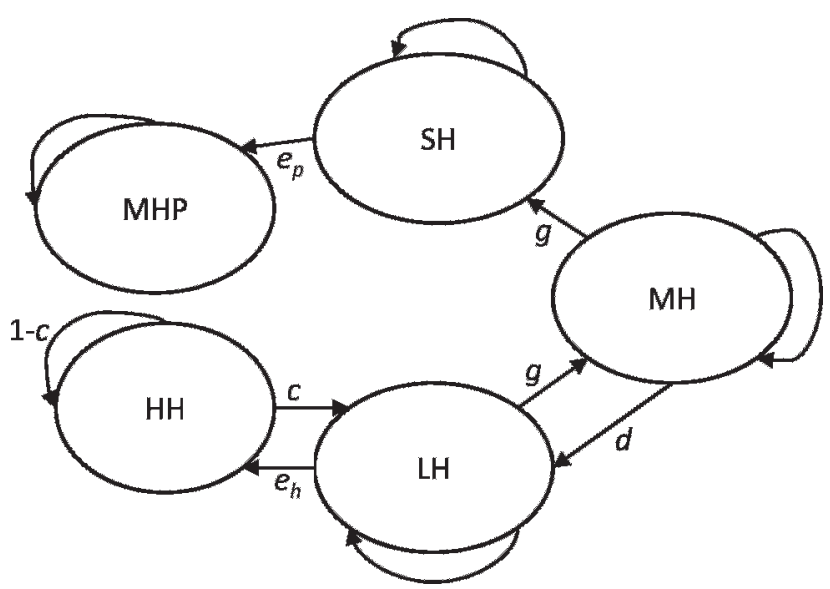

Figure 3. Model depicting the stand-level transitions among the five riparian forest stand states, which was used to predict the outcome of the treatment alternatives for hemlock woolly adelgid (HWA). Riparian forest states follow Kirksey et al. (2004; Table 3) and transitions between states are described in the text. $\mathrm{HH}=$ healthy hemlock stand, $\mathrm{LH}=$ lightly infested and healthy to lightly declining hemlock stand, $\mathrm{MH}=$ moderately to severely infested and moderately declining hemlock stand, $\mathrm{SH}=$ moderately to severely infested and severely declining hemlock stand, and MHP = mature hardwood- or pine-dominated stands. $e_{p}=$ probability of a severely infested stand going extinct, $g=$ growth rate, $d=$ decline rate, $e_{h}=$ probability of a lightly infested stand going extinct, $c=$ colonization rate.
Kirksey et al. 2004) in as few as $12 \mathrm{y}$ in the northern United States (Orwig et al. 2002) and at potentially higher rates farther south (Evans and Gregoire 2007). The average time from infestation with hemlock woolly adelgid to reach the SH state (severe infestation or severe decline) was assumed to be $15 \mathrm{y}$ in our model. Survival of hemlock woolly adelgid is primarily limited by minimum winter temperatures and the highest predicted survival rates in the eastern United States include areas in Tennessee (Trotter and Shields 2009). We used these data to estimate the growth $(g)$ transition probability and assumed hemlock woolly adelgid populations would grow to the next state in $5 \mathrm{y}$.

Silvicultural techniques can stimulate regeneration of understory hardwoods and pines if used aggressively (e.g., felling dying hemlocks to increase solar exposure in conjunction with herbicides or prescribed burning to eliminate competing understory vegetation). We predicted that silvicultural techniques would reduce the amount of time without mature riparian forest cover by one-quarter.

The effectiveness of predator beetles for controlling hemlock woolly adelgid invasion at the landscape level is poorly known (R. Rhea, U.S. Forest Service, personal communication) and represented a source of structural uncertainty in the decision analysis. Single-tree experiments indicate predator beetles may reduce hemlock woolly adelgid abundance by $>50 \%$ (e.g., Laricobius nigrinus; Lamb et al. 2006), and releases of multiple species of predator beetle may be more effective than single-species releases (Flowers et al. 2006). Based on these limited data, we considered the two predator beetle species as a biological control agent in the decision analysis, but incorporated uncertainty regarding their effectiveness. We utilized a range of values (hereafter, most effective and least effective beetles) to assess uncertainty in predator beetle effectiveness at controlling hemlock woolly adelgid populations. These values were incorporated in the growth rate parameters $(d, g)$ in the model (Table 6). We only evaluated uncertainty in $d$ and $g$ because there is little evidence that predator beetles can cause extinction 
Table 6. Initial model parameters including transition probabilities between model states, treatment costs for one 8-ha (20-acre), high-quality hemlock stand, and species habitat preference values for simulation to assess tradeoffs at maximizing healthy mature forest cover based on expected changes due to each of five management strategies in the second prototype. Transitions between stand states $\left(g, e_{h}, d, e_{p}\right)$ are shown in Figure 3. Colonization rate $(c)$ increased exponentially based on the number of infested stands as described in the text. Silvicultural treatment caused all stands in the $\mathrm{MH}$ state in time $t$ to transition to the SH state in time $t+1$.

\begin{tabular}{|c|c|c|c|c|c|}
\hline \multirow[b]{2}{*}{ Treatment } & \multicolumn{4}{|c|}{ Transition probability } & \multirow[b]{2}{*}{ Cost (U.S.\$) } \\
\hline & Growth $(g)$ & $\begin{array}{l}\text { Extinction from } \\
\text { LH state }\left(e_{h}\right)^{*}\end{array}$ & $\begin{array}{l}\text { Decline from } \mathrm{MH} \\
\text { to LH state }(d)^{*}\end{array}$ & $\begin{array}{l}\text { Extinction from } \\
\text { SH state }\left(e_{p}\right)^{*}\end{array}$ & \\
\hline No treatment & 0.2 & 0 & 0 & 0.01 & \\
\hline Predator beetles & $0.01-0.10$ & 0 & $0.3-0.6$ & 0.01 & 10,000 \\
\hline Fungi & 0.08 & 0 & 0.6 & 0.01 & 1,000 \\
\hline \multirow[t]{2}{*}{ Silviculture } & & 0 & 0 & 0.04 & 2,200 \\
\hline & & \multicolumn{4}{|c|}{ Habitat preference score $(0-1)$} \\
\hline Species & & $\mathrm{HH} / \mathrm{LH}^{*}$ & $\mathrm{MH} / \mathrm{SH}^{*}$ & & MHP* \\
\hline Swainson's warbler & & 1 & 0.5 & & 0.5 \\
\hline Blackside dace & & 1 & 0.7 & & 1 \\
\hline Alleghany woodrat & & 1 & 0.5 & & 1 \\
\hline
\end{tabular}

${ }^{*} \mathrm{HH}=$ healthy hemlock stand, $\mathrm{LH}=$ lightly infested and healthy to lightly declining hemlock stand, $\mathrm{MH}=$ moderately to severely infested and moderately declining hemlock stand, $\mathrm{SH}=$ moderately to severely infested and severely declining hemlock stand, and MHP = mature hardwood- or pine-dominated stands.

of hemlock woolly adelgid populations $\left(e_{h}\right)$ or slow the decline of stands in the SH state $\left(e_{p}\right)$. The cost of applying the predator beetles was constant regardless of beetle effectiveness.

The fungus Lecanicillium muscarium is being developed and tested for government approval as a biological control agent for hemlock woolly adelgid (Cheah et al. 2004; S. Costa, University of Vermont, personal communication). Small-scale trials using single branches significantly reduced hemlock woolly adelgid populations and did not affect survival of predator beetle populations (Cheah et al. 2004), which suggests these two control methods could be used simultaneously. Although other trials found no reduction in hemlock woolly adelgid populations, this has been attributed to application when cool temperatures and the development stage of hemlock woolly adelgid in the autumn were not optimum for fungal effectiveness (Costa et al. 2005). In 2009 the fungus was applied aerially to 12 0.5-ha (1.25-acre) plots on the project area to test biological control at the landscape level. The application used a specially formulated microfactory technology that allows the fungus to grow after application (i.e., fungal conidia in whey-based carriers with trade names Mycotal with MycoMax; Koppert Biological Systems, Berkel en Rodenrijs, the Netherlands). Preliminary results indicated a nearly $60 \%$ reduction in hemlock woolly adelgid populations (S. Costa, personal communication). Because of its potential, we integrated this prediction for the effectiveness of the fungus as a biological control agent in our model (Table 6).

The pesticide imidacloprid is highly effective at eliminating hemlock woolly adelgid and is safe in recommended dosages, but it is expensive to purchase and apply (Cowles 2009; R. Rhea, personal communication). We did not consider it in the tradeoff analysis in the second prototype for four reasons: the prohibitive cost and potential for public concern as identified in the first prototype, the preference of TWRA for predator beetles and fungi rather than pesticide to control hemlock woolly adelgid, the fact that all three treatments (i.e., pesticides, fungi, and predator beetles) would be applied in similar management situations (i.e., states), and to reduce complexity in the tradeoff analysis.
We combined the alternative management actions in strategies that may be used on the landscape. We developed possible management strategies that incorporate three treatment options, silviculture, fungi, and predator beetles. The treatment options were used in different situations depending on the state of the riparian forest stand. Silviculture was used as a late intervention strategy and was used only if the stand was beyond return to a healthy hemlock stand ( $\mathrm{SH}$ state) to promote conversion to a hardwood- or pine-dominated stand. Predator beetles were used as an early intervention strategy and used only if the infestation was detected early and the stand was in the LH state. Fungi were used as an early and intermediate intervention strategy and applied to the LH and $\mathrm{MH}$ states. Because we were unsure of the predator beetle effectiveness, we incorporated a range of predator beetle effectiveness in predictive models. The management strategies that resulted are as follows: 1) no treatment, 2) biological control agent including insect-killing fungi or predator beetles, and 3) biological control agent combined with silviculture.

Examining consequences and tradeoff analysis. We assessed the potential of each of the three management strategies to maximize mature forest cover constrained by cost. We defined mature forest cover as hemlock stands in the $\mathrm{HH}$ state or $\mathrm{LH}$ state and MHP stands. We estimated the cost of applying each treatment to an average 8.0-ha (20-acre), high-quality hemlock stand. The cost for predator beetles were estimated based on Sasajiscymnus tsugae and included laboratory costs of rearing the beetles and labor to transport and release the beetles. We estimated that we need approximately 10,000 predator beetles to treat an 8.0-ha (20-acre) stand at a cost of U.S.\$1/beetle (R. Rhea, personal communication). The cost of applying the predator beetles was constant regardless of beetle effectiveness. The cost of Laricobius nigrinus is higher but fewer beetles are needed per stand. The cost of applying the silvicultural treatment was primarily labor and equipment and was based on TWRA rates of U.S.\$270/ha (\$110/acre as estimated by B.N.M.). The cost of applying fungi was calculated at the dosage that produced the best preliminary results, 25 L/ha (2.7 gallons/acre; mixture of Mycotal with 


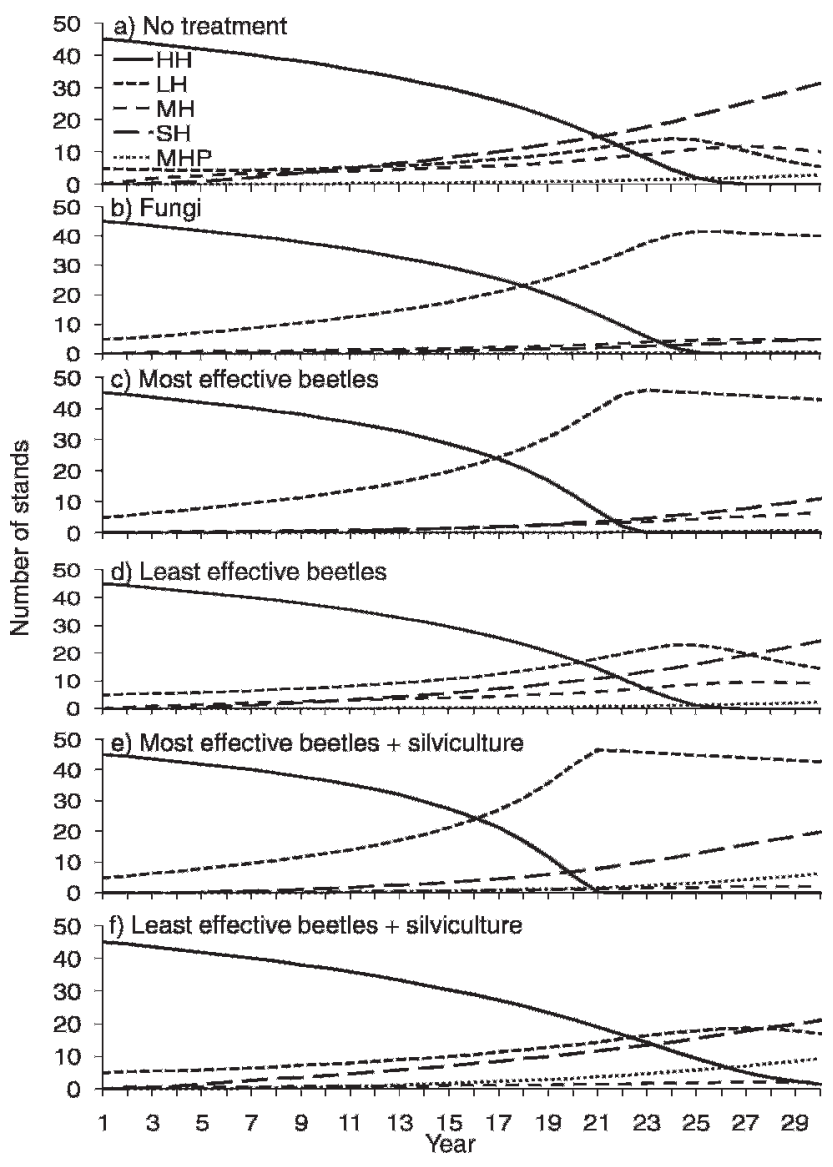

Figure 4. Change in number of stands in each of the five riparian forest states over the 30 y under six management strategies: no treatment (a), early and intermediate intervention at the lightly infested and healthy to lightly declining hemlock stand (LH) and moderately to severely infested and moderately declining hemlock stand $(\mathrm{MH})$ state with fungi (b), early intervention at the LH state with most effective predator beetles (c), early intervention at the LH state with least effective predator beetles (d), early intervention at the $\mathrm{LH}$ state with least effective predator beetles plus late intervention at the $\mathrm{MH}$ and moderately to severely infested and severely declining hemlock stand (SH) states with silviculture (e), and early intervention at the LH state with most effective predator beetles plus late intervention at the $\mathrm{MH}$ and moderately to severely infested and severely declining hemlock stand (SH) states with silviculture (f) in the second prototype. $\mathrm{HH}=$ healthy hemlock stand, $\mathrm{MHP}=$ mature hardwood- or pine-dominated stands.

MycoMax) and included helicopter and fungal costs (S. Costa, personal communication). The fungal treatment cost U.S.\$120/ ha $(\$ 50 /$ acre). Because we were interested in habitat remaining for NCFRHCP-covered species, we also monitored the habitat value of stand in each state. Habitat preference scores were for the target species were based on preliminary habitat models for each species on the Cumberland Plateau and Mountains ecoregion (Table 6; S.M.B., unpublished data). Swainson's warbler is a hemlock canopy specialist, blackside dace is an aquatic species, and Alleghany woodrat is a mature forest species.

To illustrate the effectiveness of each strategy, we designed a simulation. We used six possible variations of the three management strategies to illustrate their potential effectiveness, no treatment, fungi, most effective beetles, least effective beetles, most effective beetles combined with silviculture, and least effective beetles combined with silviculture. We started with a set of 50 hypothetical hemlock stands, 5 of which began

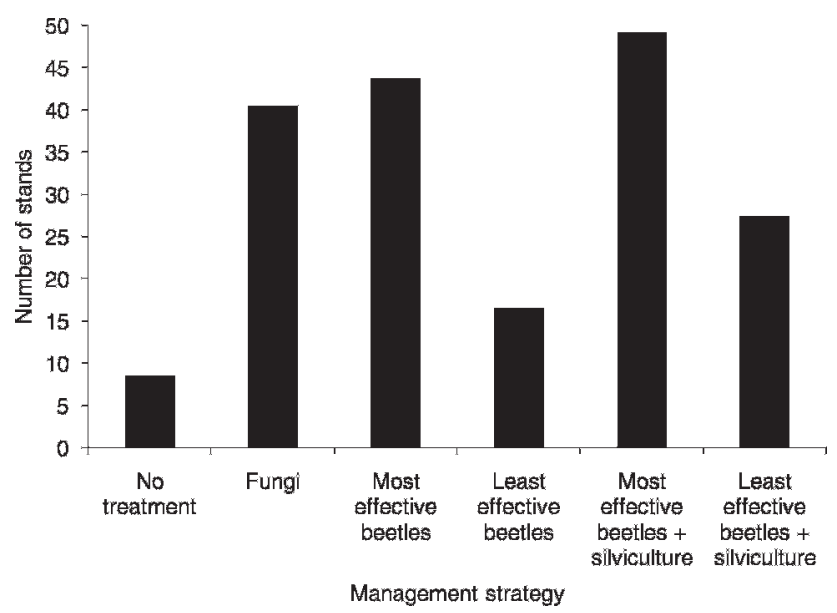

Figure 5. Number of stands remaining in mature forest cover (healthy hemlock stand $[\mathrm{HH}]$, lightly infested and healthy to lightly declining hemlock stand $[\mathrm{LH}]$, and mature hardwood- or pine-dominated stands $[\mathrm{MPH}]$ states) after $30 \mathrm{y}$ under each of the six management strategies in the second prototype.

in the LH state, and projected the consequences of applying the same management alternative annually for the 30-y planning horizon. During the simulation, we monitored the number of stands in healthy mature forest cover (Figure 4), the habitat value for each of three species covered by the NCFRHCP, and the cost, which was treated as a constraint (Table 6).

In the simulation, the number of stands remaining in mature forest states $(\mathrm{HH}, \mathrm{LH}$, or MHP) at the end of the 30-y simulation was maximized by early intervention with predator beetles on stands in the LH state combined with late intervention with silviculture on stands in the $\mathrm{MH}$ or $\mathrm{SH}$ states (Figure 5). Habitat value for each of the species generally followed the same pattern that mature forest cover did with the species differing only slightly in the degree of change due to the changes in forest cover (Figure 6). In our simulation, costs were highest for strategies with predator beetles combined with silviculture, but predator beetle effectiveness influenced cost for two reasons (Figure 7). First, least effective beetles were unable to maintain stands in a condition that would be treated with that strategy (i.e., the hemlock woolly adelgid populations grew through the LH state and costs were lower because fewer stands remained in the LH state to treat with predator beetles). Second, we augmented predator beetle populations each year in the simulation, so the cost of the treatment was additive each year. When cost was taken into account by dividing the number of mature stands by the total cost, early intervention without silviculture was the best strategy. Thus, the cost constraint was determinative in the decision process. If the decision was not constrained by cost then it was better to combine biological control with silviculture. If cost was a constraint then the cost of silviculture could exceed budgets and early intervention alone would be the best strategy. Treatment with fungi at the LH and $\mathrm{MH}$ state was intermediate in cost and effectiveness to the other strategies. It is noteworthy that there is no value in resolving the uncertainty in predator beetle effectiveness for the decision of whether or not to combine silviculture with early intervention. The cost constraint determines the optimality of that decision. However, with regard to selection of biological control agent, there is a potential gain in resolving that uncertainty. 


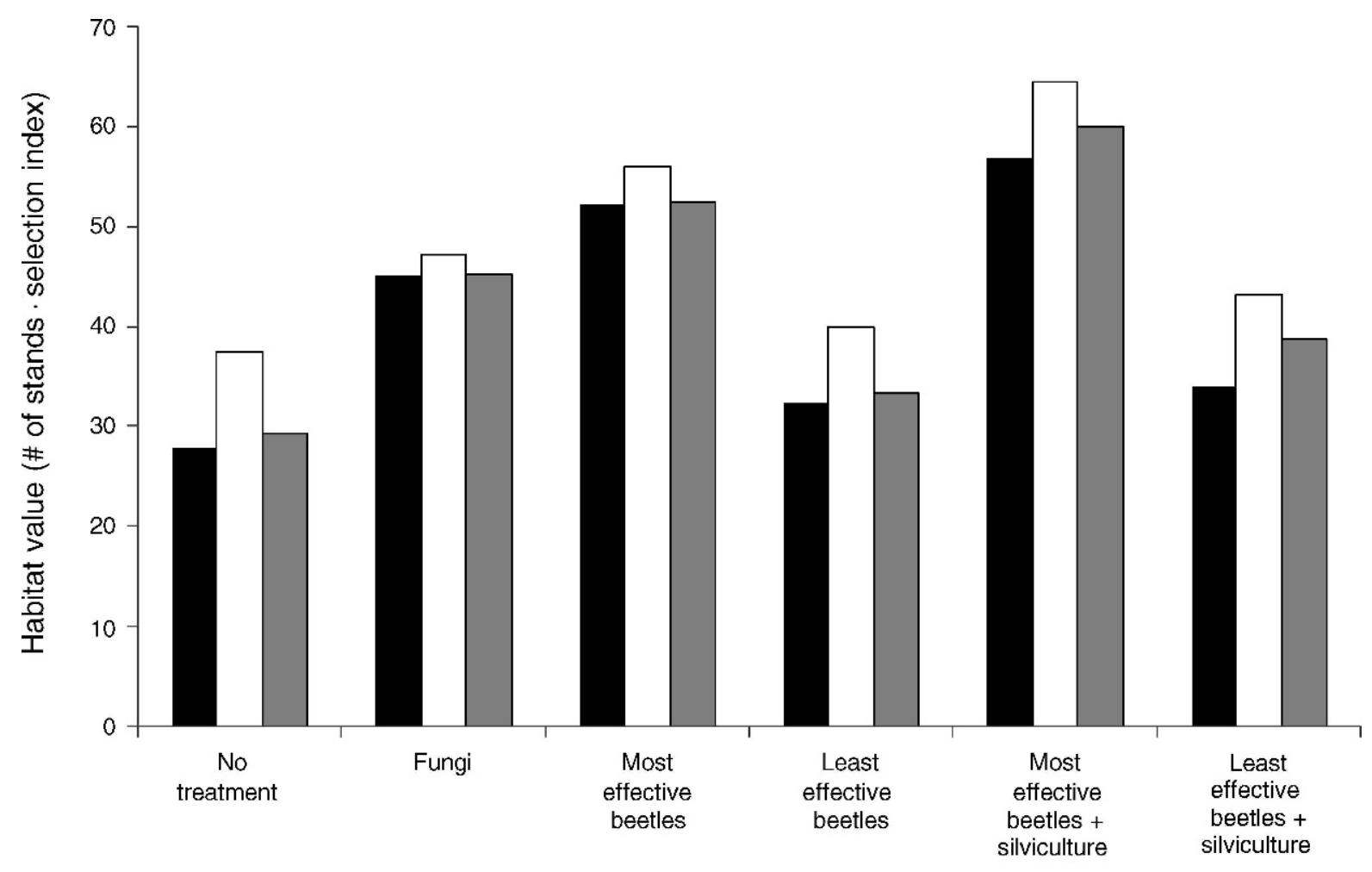

Management strategy

Figure 6. Habitat value for three conservation targets, Swainson's warbler (black bars), blackside dace (white bars), and Alleghany woodrat (gray bars), after 30 y under each of the six management strategies in the second prototype. Habitat preference values for each species are shown in Table 6.

Dealing with uncertainty using expected value of perfect information (EVPI). There are many sources of uncertainty to be considered in ecological decisions. The essential challenge is to determine which uncertainties are relevant to decisionmaking. Epistemic uncertainty is an incomplete understanding about biological mechanisms that limits the effectiveness of

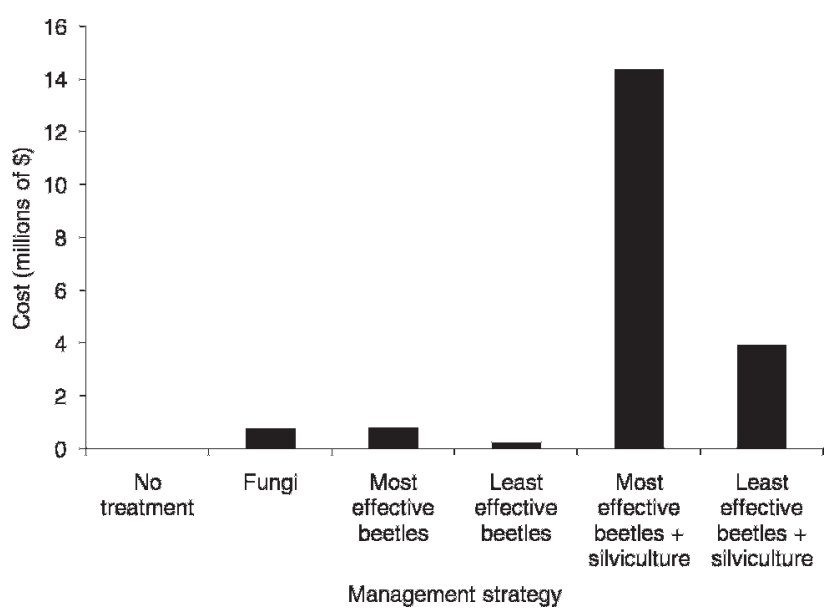

Figure 7. Total cost after $30 \mathrm{y}$ following each of the six management strategies in the second prototype. Annual costs were calculated by multiplying the number of stands in a given state by the cost of treatment under the given strategy and summed over the $30 \mathrm{y}$. To simplify the analysis, we assumed the cost of treatment would be incurred in every year (i.e., effectiveness of treatments did not transfer from one year to the next). management. We represented structural uncertainty by one predictive model for less effective beetles and another for more effective beetles. One technique, which we use here, is to calculate the value of resolving uncertainty (EVPI).

To determine the potential importance in resolving the uncertainty in predator beetle effectiveness prior to selecting the biological control agent (i.e., insect-killing fungi vs. predator beetle), we calculated the EVPI (Clemen and Reilly 2001). The EVPI in this case is the difference in the number of mature forest stands after $30 \mathrm{y}$ that would result if the uncertainty in predator beetle effectiveness was resolved before deciding on the biological control agent compared to the number of mature stands if the decision was made without first resolving the uncertainty.

The decision tree in Figure 8, which shows the pathways in the decision, can help see how we calculated the EVPI. Model parameters for calculating expected values were taken from Table 6, and it was assumed that it was equally likely that the beetles are least or most effective. Starting from the left side of the tree, the first decision node was whether or not to resolve the beetle effectiveness before selecting the biological control agent. The lower branch led to selecting the biological control agent without resolving beetle effectiveness. In that case, it was better (the expected number of stands is higher-40.40 vs. 30.12) if insect-killing fungi were selected. In contrast, the upper branch represents what would happen if beetle effectiveness was resolved prior to selecting the biological control agent. In that case, the selection depended on beetle effectiveness, but the expected number of stands was 42.05 . Thus, more mature stands would be expected if the uncertainty in beetle effectiveness was resolved prior to selection. 


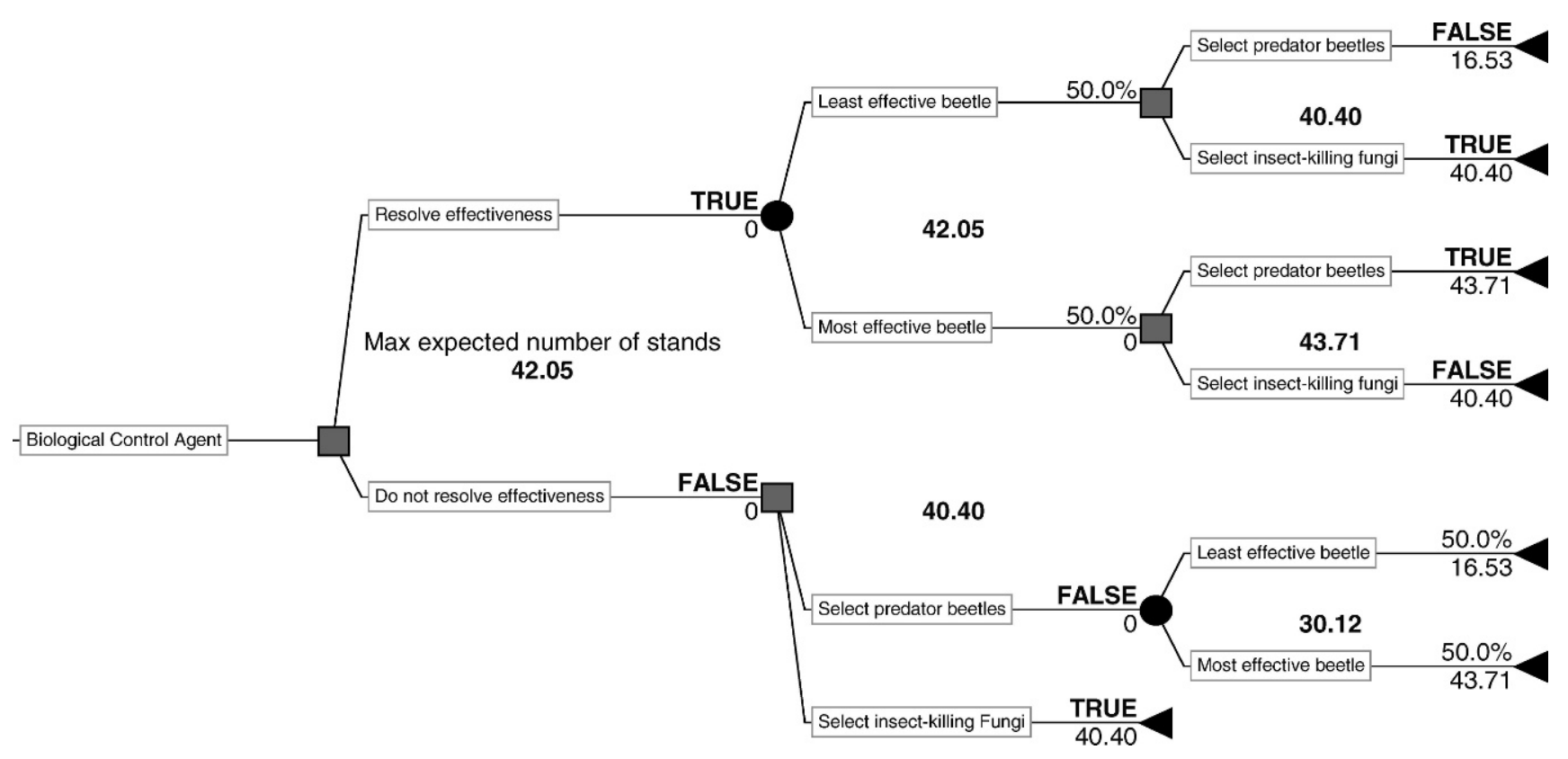

Figure 8. Decision tree for selection of biological agent for controlling growth rate of hemlock woolly adelgid infestation. Decision nodes are represented by squares, and chance events are represented by circles. Probabilities of chance events are shown as percentages. For example, there is an equal probability that predator beetles are least or most effective. Bold numbers are the expected number of mature stands after $30 \mathrm{y}$, given the decision pathway. The TRUE/FALSE labels indicate the optimality of the decision pathway with TRUE indicating the best decision to take at each node. Precision Tree under Palisade DecisionTools (ver 5.5) was used to generate the decision tree.

The EVPI represented the potential gain in measurable attributes if uncertainty is resolved. In this case, EVPI was the 1.65 mature stands or $4.1 \%$ increase over the number of stands expected if uncertainty was not resolved. Expected value of perfect information is sensitive to underlying model parameters. Table 7 shows EVPI as percent increase for a range of infestation growth rates. As beetle effectiveness increased (i.e., infestation growth decreases), the potential gain increased. The potential gain was also sensitive to the prior probability assigned to beetle effectiveness. If it becomes more likely that beetles are highly effective, then the potential gain (EVPI) will increase.

Table 7. Percentage increase in mature forest stands after $30 \mathrm{y}$ that would be expected if uncertainty in beetle effectiveness was resolved prior to selecting a biological agent for early intervention to control hemlock woolly adelgid. The expected increase in stands is sensitive to the assumed growth rates of the adelgid infestation for the least and most effective predator beetle. Insect-killing fungus was the alternative biological control agent. Calculations were based on the expected value of perfect information (Figure 8).

\begin{tabular}{lccccc}
$\begin{array}{l}\text { Ratio of growth }(\boldsymbol{g}) \\
\text { for least to most } \\
\text { effective beetle }\end{array}$ & \multicolumn{3}{c}{ Growth $(\boldsymbol{g})$ for least effective beetle } \\
\cline { 2 - 6 } & $\mathbf{0 . 0 5 0}$ & $\mathbf{0 . 0 7 5}$ & $\mathbf{0 . 1 0 0}$ & $\mathbf{0 . 1 2 5}$ & $\mathbf{0 . 1 5 0}$ \\
\hline 5 & 4.10 & 0.49 & 0.00 & 0.00 & 0.00 \\
\hline 7 & 6.26 & 3.57 & 0.99 & 0.00 & 0.00 \\
\hline 9 & 7.48 & 5.35 & 3.28 & 1.27 & 0.00 \\
\hline 11 & 8.27 & 6.51 & 4.78 & 3.09 & 1.45 \\
\hline 13 & 8.82 & 7.32 & 5.84 & 4.39 & 2.97 \\
\hline 15 & 9.23 & 7.92 & 6.62 & 5.35 & 4.10 \\
\hline
\end{tabular}

We focused on the uncertainty in predator beetle effectiveness because more data are available for beetles to document a range of possible effectiveness. Only preliminary data exists for effectiveness of insect-killing fungi, and we felt we could not adequately characterize the uncertainty in this biological control agent. We show an example EVPI calculation, and EVPI could be calculated for the uncertainty in fungi effectiveness once more data are available.

It is our experience, as we found with predator beetle effectiveness, that uncertainties do not need to interfere with good decision-making. It is important to separate an academic interest in resolving uncertainty from the value of resolving uncertainty before making a decision. Another technique to determine whether optimal decisions are affected by uncertainty that is equally valuable and will be utilized after our models are fully developed is to conduct a sensitivity analysis.

Consideration of an adaptive approach. Adaptive management provides a formal approach to sequential decision-making with an emphasis on the reduction of uncertainty (Williams et al. 2002). This process relies on predictive models to represent different hypotheses about the response of a system to management (Lyons et al. 2008). A critical aspect of this process is the development of credibility measures for each model, which represent relative beliefs or weights. Learning through adaptive management occurs when each model's prediction is confronted with observations of the system and these relative belief measures are updated through Bayes' theorem (Williams et al. 2002). Thus, monitoring in adaptive management serves as a basis to update our relative beliefs about the different predictive models, to measure the state of the system, and to evaluate progress toward our management objectives (Nichols and Williams 2006). During the workshop, we developed an initial conceptual framework for adaptive management of hemlock woolly adelgid in Tennessee. We considered structural uncertainty by using alternative models to represent the colonization process of hemlock woolly adelgid 
(linear and exponential). During model development, we were also concerned about the dimensionality of our model structure (i.e., the number of state and decision variables), because we anticipated the potential of using stochastic dynamic programming to determine an optimal set of actions relative to our fundamental ecological objective.

Considering the necessary elements of adaptive management while developing a system model provided an ideal context for evaluating monitoring needs within our decision framework. We also recognized the need to collect additional information to refine our framework. Additional information needs include: 1) documenting existing hemlock woolly adelgid control efforts (e.g., Great Smoky Mountains National Park) to ensure that we are considering all relevant management options and possible outcomes, and 2) sampling extant hemlock stands and calibrating remote sensing or aerial photograph data to characterize variation in hemlock stands on wildlife management areas in order to parameterize the spatially explicit model and help ascertain the current state of hemlock stands near known infestations. This information will help us refine the states included in the initial model by considering the range of hemlock stand density and quality on the landscape (i.e., model stands other than those we defined as high quality). We can then refine management alternatives based on 1) range of hemlock composition, 2) proximity or presence of NCFRHCP-covered species, 3) degree of infestation, 4) hemlock health, 5) understory structure and composition, and 6) location relative to infestation. The information will also help to refine the measurable attributes that define the objective of maintaining mature riparian forest cover.

For our prototype simulation, we monitored the state of 50 stands under five management strategies with the objective of maximizing the number of $\mathrm{HH}, \mathrm{LH}$, and MHP states. Although this simulation had limitations (e.g., it was neither dynamic nor spatially explicit), it helped us to evaluate the possible outcomes of management and assess uncertainty related to the effectiveness of predator beetles, and it reinforced the idea that monitoring needs to be state-based to make the decision on how to treat stands. Monitoring data will define the stand state based on the stand health and infestation categories we developed during the workshop, and these states will, in turn, inform decisions about where and how to treat infested stands; we thus need to develop the spatial context for monitoring and extent of monitoring. We also discussed the need for monitoring riparian areas stratified by watersheds to detect new infestations, as well as allocating more effort toward known points of infestation to inform treatment decisions and help with model discrimination. These issues will be resolved through power analysis and cost-benefit analysis as we develop the monitoring program; monitoring techniques will follow those developed and recommended by Costa and Onken (2006).

\section{Discussion}

\section{Value of decision structuring}

The two most valuable contributions of the structured decision-making process were 1) clarification and expansion of our objectives, and 2) application of the tools used to assess consequences and tradeoffs among alternative actions. For the first prototype, our focus was on minimizing habitat loss for the NCFRHCP-covered species, and we considered two other objectives, budget and public acceptance, that had not been incorporated explicitly into our decision framework. Following the first prototype, the team realized that we intrinsically valued hemlocks and that this should be a fundamental objective during the decision-making process.

Application of techniques to predict consequences of management actions resulted in valuable insights. Conceptual modeling encouraged clear thinking about information and ideas relevant to the decision problem and highlighted aspects of the decision framework that needed careful definition. Defining the possible hemlock stand conditions where management could occur given the health and infestation level (i.e., state) of a stand was an important step in refining and modeling our alternative management actions in the second prototype. Predicting consequences allowed us to evaluate the influence of uncertainty on the decisions. Our initial assumption was that uncertainty regarding predator beetle effectiveness was a significant impediment to good decision-making. At least for the decision framework that we considered, there was some potential gain in measurable attributes in resolving uncertainty when selecting biological control agents. However, there was no gain in resolving uncertainty with regard to whether or not to combine silviculture with early intervention. In that later case, the optimal decision depended on the cost constraint. These advances highlight the need for multiple iterations of the prototyping process.

\section{Rapid prototyping process}

We worked through two iterations of the decision-prototyping cycle during the workshop. The three largest challenges for the team were defining the spatial scale being considered (e.g., stand- vs. wildlife management area-scale), reducing complexity of the decision to a manageable level for a 1-wk workshop, and proceeding forward using team-member opinions and available, albeit sometimes incomplete, information.

By prototyping two possible solutions, we gained insights and identified shortcomings, which can be incorporated and corrected in future prototypes. For example, we did not adequately define our spatial scale when the decision was framed initially. We defined our spatial scale of the stand after we started to define our management alternatives and put together our alternative portfolios for the first prototype. This oversight became apparent after we started to define our management alternatives because different alternatives were being suggested that worked at different spatial scales. In our second prototype, we defined spatial scale more carefully from the beginning.

Prototyping requires that some complexity inherent in the decision problem be reduced or ignored. We found it useful to both simplify and add complexity when needed. A seemingly infinite amount of complexity could be included in any ecological decision, but it is important to evaluate the sensitivity of decision-making to different factors and sources of uncertainty (e.g., our EVPI analysis). As a rule, decision analysis should include only those complexities that affect the decision. We reduced the complexity of our management situation by defining a single stand condition and defining a temporal scale to work with for purposes of the prototyping process. For the first prototype, we reduced the range of possible stand conditions by defining one stand condition based on hemlock stand attributes and level of infestation: a high-quality hemlock stand with a light level of hemlock woolly adelgid infestation. We did this after starting to put together our alternative portfolios because different alternatives were being proposed based on different stand conditions (e.g., \% hemlock composition, understory composition, degree of infestation, and stand health). This complexity made it difficult 
to adequately define our alternatives. For the first prototype, we dealt with a management action carried out at one point in time, whereas for the second prototype, we reincorporated two pieces of complexity that were removed from the first prototype; management actions were carried out over the 30-y NCFRHCP duration, and a high-quality hemlock stand could become infested at four categorical levels (Table 3; Figure 3).

Perhaps the biggest challenge for our team was generating the prototypes using team-member opinions and information available during the workshop. At the core of this challenge was how to parameterize the models used in the decision analysis. We had three options, empirical data, literature for our system or species or a similar system or species, and expert elicitation, and we used a combination of all three approaches. We used preliminary habitat models for the covered species (S.M.B., unpublished data) and relied on published literature and unpublished reports. Although it made some team members uncomfortable, we also worked from expert opinion within the team and contacted one expert outside the team (R. Rhea, personal communication) to define effectiveness of some treatment options and to assign associated costs. The details associated with individual treatments and the interaction among multiple treatments occasionally created uncertainty that stifled our progress, but the coaches helped us to focus on the process rather than the details. Two of the biggest lessons we took from this challenge were that novel research and monitoring efforts should be designed to be relevant to management decisions and that we should build upon the decision models we started to develop during the workshop and use them to inform and design new research and monitoring. We also need to conduct a sensitivity analysis to determine if the model is sensitive to the information provided by experts or gathered from the literature.

\section{Future prototyping efforts and recommendations}

We proceeded through the two rapid prototypes with little spatially explicit information and made many simplifying assumptions during the rapid prototyping process (e.g., working only with high-quality hemlock stands). Areas for further development include focus on resolving important sources of uncertainty and generating support for planning and implementation.

We identified sources of uncertainty that required assumptions in the predictive models or simplifications in the complexity of the decision. Following others (e.g., Williams 1997), we categorized sources of uncertainty into partial observability, partial controllability, epistemic uncertainty, and environmental stochasticity to help plan our response to each type of uncertainty. Partial observability is an inability to accurately monitor the status of a population due to biased observations or sampling error. Sources of partial observability included determining location and characteristics of hemlock stands and the presence and level of hemlock woolly adelgid infestation. Human perception and reaction to treatment or nontreatment is also partially observable. The influence of partial observability will be assessed during design of the monitoring program. Partial controllability refers to uncertainty in predicting management outcomes. As a special case of partial controllability, there is uncertainty in how agencies will implement recommendations from a structured decisionmaking process. The team will present the results of this workshop to institutions that make up Tennessee Interagency Hemlock Woolly Adelgid Task Force. We identified several impediments to implementing recommendations. The task force might not be willing to collaborate with the NCFRHCP-based planning, and TWRA might lack flexibility in decision-making. Of course, uncertainty in the availability of funding and personnel will affect ability to apply treatments and monitor results. Epistemic uncertainty is an incomplete understanding about biological mechanisms that limits the effectiveness of management. As an example of how to deal with epistemic uncertainty, we represented structural uncertainty by one predictive model for less effective beetles and another for more effective beetles and calculated EVPI. Parametric uncertainty could be represented by variance of model parameters (e.g., transition probabilities in the state-based model), and we can assess this through sensitivity analysis of the final models. Finally, environmental stochasticity includes variation in climate, landscapes, and other unpredictable influences that lead to uncertainty about the effects of management, such as climate change and drought. The importance of environmental stochasticity will be considered during design of the monitoring program.

We recommend that the Tennessee Interagency Hemlock Woolly Adelgid Task Force and the NCFRHCP utilize the initial decision prototype to move forward with efforts to control the invasion of hemlock woolly adelgid in the state of Tennessee and the NCFRHCP project area. In two iterations of the rapid structured decision-making process, we developed a decision framework and suite of tools that can be used by TWRA managers to which determine hemlock woolly adelgid management strategies optimize control of this pest based on the control techniques and financial resources available. There are many other details that need to be integrated into future development of a management plan for this pest, but developing the decision framework was a major advance and should prove valuable to TWRA's efforts to manage the effects of hemlock woolly adelgid invasion.

Our team gained at least five principal insights during the structured decision-making process. First, do not underestimate the value of having fresh eyes take part in complex decisions and processes. Second, analytically skilled persons are important in the structured decision-making process. Third, devoting time to making smart decisions can lead to substantial cost savings over time. For example, without using this process, we may have been successful at attaining beetles and grant money but not have known how to successfully implement our strategy. Fourth, it is worth the time and effort to gather the best information. Using the structured decision-making process, we were able to focus in on the most relevant information for the decision. Finally, rapid prototyping is not the endpoint; rather, it is the beginning of the structured decision-making process, particularly when adaptive management is incorporated.

\section{Acknowledgments}

A special thanks to the USFWS and USGS for sponsoring the National Conservation Training Center Structured Decisionmaking Workshop. Thanks to Donna Brewer and Jean Cochrane for organizing the workshop and providing invaluable guidance. Thanks to the anonymous subject editor, Scott Costa, and the two other anonymous reviewers for their editorial guidance. Development of the Northern Cumberlands Forest Resources Habitat Conservation Plan is supported by a planning assistance grant from the USFWS to Tennessee Wildlife Resources Agency. More information on the habitat conservation plan can be found at www.cumberlandhcp.org. More information on the USFWS/USGS Structured Decision- 
making Workshops can be found at http://training.fws.gov/ bart/Course_descriptions/ECS3159.htm.

\section{References}

Bogich T, Shea K. 2008. A state-dependent model for the optimal management of an invasive metapopulation. Ecological Applications 18:748-761.

Cheah C, Montgomery M, Salom S, Parker BL, Costa SD, Skinner M. 2004. Biological control agents. Pages 5-16 in Reardon $R$, Onken B, technical coordinators. Biological control of hemlock woolly adelgid. Morgantown, West Virginia: U.S. Department of Agriculture, Forest Service, Forest Health Technology Enterprise Team Report FHTET-2004-04.

Clemen RT, Reilly T. 2001. Making hard decisions. Pacific Grove, California: Duxbury.

Costa S, Onken B. 2006. Standardized sampling for detection and monitoring of hemlock woolly adelgid in eastern hemlock forests. Morgantown, West Virginia: U.S. Department of Agriculture, Forest Service, Forest Health Technology Enterprise Team Report FHTET-2006-16.

Costa SD, Parker BL, Gouli V, Brownbridge M, Skinner M, Gouli S. 2005. Insect-killing fungi as a component of hemlock woolly adelgid integrated pest management. Pages 155-160 in Onken B, Reardon R, compilers. Proceedings of the 3rd Symposium on Hemlock Woolly Adelgid in the Eastern United States. Asheville, North Carolina: U.S. Department of Agriculture, Forest Service.

Cowles RS. 2009. Optimizing dosage and preventing leaching of imidacloprid for management of hemlock woolly adelgid in forests. Forest Ecology and Management 257:1026-1033.

Drake JM, Bossenbroek JM. 2004. The potential distribution of zebra mussels (Dreissena polymorpha) in the USA. BioScience 54:931-941.

Evans AM, Gregoire TG. 2007. A geographically variable model of hemlock woolly adelgid spread. Biological Invasions 9:368-382.

Flowers RW, Salom SM, Kok LT. 2006. Competitive interactions among two specialist predators and a generalist predator of hemlock woolly adelgid, Adelges tsugae (Hemiptera: Adelgidae) in south-western Virginia. Agricultural and Forest Entomology 8:253-262.

Graham J, Simpson A, Crall A, Jarnevich C, Newman G, Stohlgren T. 2008. Vision of a cyberinfrastructure for nonnative, invasive species management. BioScience 58:263-268.

Gregory R, Keeney R. 2002. Making smarter environmental management decisions. Journal of the American Water Resources Association 33:1601-1612.

Gregory R, Long G. 2009. Using structured decision-making to help implement a precautionary approach to endangered species management. Risk Analysis 29:518-532.

Grosholz ED. 1996. Contrasting rates of spread for introduced species in terrestrial and marine systems. Ecology 77:16801686.

Hammond J, Keeney RL, Raiffa H. 1999. Smart choices: a practical guide to making better decisions. Cambridge, Massachusetts: Harvard Business School Press.

Havill NP, Montgomery ME, Yu G, Shiyake S, Caccone A. 2006. Mitochondrial DNA from hemlock woolly adelgid (Hemiptera: Adelgidae) suggests cryptic speciation and pinpoints the source of the introduction to eastern North America. Annals of the Entomological Society of America 99:195-203.

Johnson FA, Moore CT, Kendall WT, Dubovsky JA, Caithamer DF, Kelley JR, Williams BK. 1997. Uncertainty and the manage- ment of mallard harvests. Journal of Wildlife Management 61:202-216.

Keeney RL, Raiffa H. 1993. Decisions with multiple objectives: preferences and value tradeoffs. Cambridge, UK: Cambridge University Press.

Kirksey J, Todd D, Strohmeier C, Tate C, Welch L, Gilpin J, Bowen B, Miller B, Carter B, Kauffman B. 2004. Hemlock woolly adelgid strategic plan and management plan for state lands in Tennessee. Nashville: Tennessee Department of Agriculture, Division of Forestry, Hemlock Woolly Adelgid Task Force Report.

Lamb AB, Salom SM, Kok LT, Mausel DL. 2006. Confined field release of Laricobius nigrinus (Coleoptera: Derodontidae), a predator of the hemlock woolly adelgid, Adelges tsugae (Hemiptera: Adelgidae), in Virginia. Canadian Journal of Forest Research 36:369-375.

Leung B, Lodge DM, Finnof D, Shogren JF, Lewis MA, Lamberti G. 2002. An ounce of prevention or a pound of cure: bioeconomic risk analysis of invasive species. Proceedings of the Royal Society of London B: Biological Sciences 269:2407-2413.

Lyons JE, Runge MC, Laskowski HP, Kendall WL. 2008. Monitoring in the context of structured decision-making and adaptive management. Journal of Wildlife Management 72:1683-1692.

McClure MS, Salom SM, Shields KS. 2001. Hemlock woolly adelgid. Morgantown, West Virginia: U.S. Department of Agriculture, Forest Service, Forest Health Technology Enterprise Team Report FHTET-2001-03.

Nichols JD, Williams BK. 2006. Monitoring for conservation. Trends in Ecology and Evolution 21:668-673.

Orwig DA, Cobb RC, D’Amato AW, Kizlinski ML, Foster DR. 2008. Multi-year ecosystem response to hemlock woolly adelgid infestation in southern New England forests. Canadian Journal of Forest Research 38:834-843.

Orwig DA, Foster DR, Mausel DL. 2002. Landscape patterns of hemlock decline in New England due to the introduced hemlock woolly adelgid. Journal of Biogeography 29:14751488.

Pimentel D, Zuniga R, Morrison D. 2005. Update on the environmental and economic costs associated with alieninvasive species in the United States. Ecological Economics 52:273-288.

Rohr JR, Mahan CG, Kim KC. 2009. Response of arthropod biodiversity to foundation species declines: the case of the eastern hemlock. Forest Ecology and Management 258: 1503-1510.

Soehn D, Taylor G, Remaley T, Johnson K. 2005. Draft environmental assessment of hemlock woolly adelgid control strategies in Great Smoky Mountains National Park. Gatlinburg, Tennessee: U.S. Department of Interior, National Park Service, Great Smoky Mountains National Park.

Trotter RT, Shields KS. 2009. Variation in winter survival of the invasive hemlock woolly adelgid (Hemiptera: Adelgidae) across the eastern United States. Environmental Entomology 38:577-587.

[USFS] United States Forest Service. 2009. Alien forest pest explorer. Pest distribution map: hemlock woolly adelgid, Adelges tsugae. Available: http://www.fs.fed.us/ne/ morgantown/4557/AFPE/. Accessed (July 2009).

Williams BK. 1997. Approaches to management of waterfowl under uncertainty. Wildlife Society Bulletin 25:714-720.

Williams BK, Nichols JD, Conroy MJ. 2002. Analysis and management of animal populations. San Diego, California: Academic Press. 